\title{
Balizko molekula fotoaktibo multifuntzionala biomedikuntzarako
}

\author{
(Multifunctional and photoactive dye tailored for biomedicine)
}

\author{
Edurne Avellanal-Zaballa, Ainhoa Oliden-Sánchez, Rebeca Sola-Llano, \\ Leire Gartzia-Rivero, Jorge Bañuelos*
}

Kimika Fisikoa Saila, Zientzia eta Teknologia Fakultatea (UPV/EHU)

LABURPENA: Argia igortzeko gai diren molekula organikoek arreta handia jaso dute azkenaldian biomedikuntzaren esparruan, batez ere diagnosian erabiltzeko helburuarekin. Izan ere, fluoreszentzia, baliabide ezin hobea da gorputzean gertatzen diren hainbat prozesu biokimiko monitorizatzeko eta biomolekulak sentikortasun handiz detektatzeko. Hori dela eta, fotoaktiboak diren kromoforoak markatzaile, zunda edo sentsore fluoreszente gisa erabiltzen dira mikroskopia fluoreszenteari esker; hots, prozesu biokimikoak jarraitzeko, organuluak ikusteko edota biomolekulak detektatzeko. Fluoreszentziarik ez duten kromoforoak, ordea, oxigeno singletea sortzeko gaitasuna ere izan dezakete eta fotosentikortzaile izaerarekin erabil daitezke terapia fotodinamikoan, minbiziaren aurkako tratamenduan. Argi dago, biofotonikako arlo baterako zein besterako eskakizun fotofisikoak guztiz bestelakoak direla eta kromoforo ezberdinak diseinatzea ezinbestekoa dela. Horregatik, lan honetan, BODIPY izeneko kromoforo-familia oinarrizko molekula-egituratzat hartzen da, diagnosian zein terapian aplikatu ahal izateko. Kromoforo mota horren abantaila nagusia da bere egitura eta propietateak erraz molda daitezkeela. Horrela, egituraren gainean ordezkapen sinple batzuk eginda hainbat eskakizun modu errazean ase daitezke. Hortaz, gure helburu nagusia da BODIPYan oinarritutako fluoroforoak zein fotosentikortzaileak garatzea eta diseinu molekularraren garrantzia azpimarratzea.

HITZ GAKOAK: fluoreszentzia, fotosentikortzaileak, kromoforoak, biofotonika.

ABSTRACT: Light-emitting organic molecules are appealing for diagnosis in biomedicine. Fluorescence is a valuable tool to visualize ongoing biochemical processes and biomolecules in the human body with great sensibility and easily. Thus, photoactive dyes are applied as fluorescent tags, probes and sensors to monitor biochemical processes, organelles and biomolecules, respectively, by means of fluorescence microscopy. Moreover, no-fluorescent dyes but able to generate singlet oxygen can be applied as photosensitizers for photodynamic therapy in the treatment of cancer. In each of the aforementioned areas dealing with biophotonics, different chromophores are required owing to the opposite photophysical signatures demanded. Herein, we propose BODIPY called chromophore as a molecular scaffold for diagnosis and therapy. The chemical versatility and tunable photophysics of this chromophoric core enables tailoring by the appropriate substitution pattern. Therefore, our aim is to highlight the importance of molecular design to develop fluorophores as well as photosensitizers based solely in BODIPY.

KEYWORDS: fluorescence, photosensitizers, chromophores, biophotonics.

\footnotetext{
* Harremanetan jartzeko / Corresponding author: Jorge Bañuelos. Kimika Fisikoa Saila, Zientzia eta Teknologia Fakultatea (UPV/ EHU), 644 PK (48080 Bilbao). . - jorge.banuelos@ehu.eus - https://orcid.org/0000-0002-8444-4383

Nola aipatu / How to cite: Avellanal-Zaballa, Edurne; Oliden-Sánchez, Ainhoa; Sola-Llano, Rebeca; Gartzia-Rivero, Leire; Bañuelos, Jorge (2021). "Balizko molekula fotoaktibo multifuntzionala biomedikuntzarako». Ekaia, 41, 2021, 207-224. (https://doi.org/10.1387/ekaia.22722).

Jasotze-data: 2021, apirilak 19; Onartze-data: 2021, uztailak 21.

ISSN 0214-9753 - eISSN 2444-3581 / (c) 2021 UPV/EHU
}

(7) $(-)$ Lan hau Creative Commons Aitortu-EzKomertziala-LanEratorririkGabe 4.0 Nazioartekoa 
Edurne Avellanal-Zaballa, Ainhoa Oliden-Sánchez, Rebeca Sola-Llano, Leire Gartzia-Rivero, Jorge Bañuelos

\section{SARRERA}

Oro har, ikusten duguna entzuten duguna baino sinesgarriagoa da. Hortik dator, hain zuzen ere, hain ezaguna den «ikusita sinistu» esaera zaharra. Bada, gorputz barruan gertatzen dena ikusteko metodo zehatzak, zuzenak eta sentikorrak garatzea ezinbestekoa da, baldin eta gaixotasunak tratatzeko sendagai edo tratamendu aproposak nahi baditugu edota horien mekanismoak ulertu nahi baldin baditugu. Gaur egun, diagnosia egiteko hainbat teknika daude eskuragarri, hala nola, $\mathrm{X}$-izpien erradiografia edo erresonantzia magnetiko nuklearra, eta sarri erabiltzen dira prozesu biokimikoak eta ingurune zelularretan dauden biomolekulen kokapena uneoro ezagutzeko, jarraitzeko eta kuantifikatzeko. Fluoreszentzia da substantzia edo konposatu kimiko batzuek, irrada bat jasotzean, argia igortzeko duten gaitasuna, eta aurreko teknologia horiekin alderatuz erreminta sinple eta zuzena da informazio kimikoa informazio analitiko bihurtzeko $[1,2]$. Horrez gain, sentikortasun oso altua (molekula mailako detekzioa ahalbidetu) eta espaziobereizmen ona (nanometro-hamarrenetatik beherakoa) erakusten ditu [3-5]. Gainera, ez-erasotzailea izateaz gain, beharrezkoa den informazioa in situ, erraz eta intuitiboki lor daiteke. Azken urteotan abangoardiako mikroskopiaren etengabeko garapenak, bioirudigintza fluoreszentearen bultzada eragin du, biomedikuntzan diagnosiaren eraginkortasuna hobetzeko asmoz.

Hori dela eta, biofotonika sustatzeko, ikertzaileek arreta handia jarri dute argitsuak eta egonkorrak diren sistema fotoaktiboen garapenean [6, 7]. Horien artean, fluoreszenteak diren molekula organiko txikiak gorakada handia jasan dute biobateragarriak direlako eta laginaren izaera manipulatu barik intereseko biomolekulen edo organuluen kokapena eta kantitatea zein den jakiten laguntzen dutelako [8]. Hori dela eta, fluoroforo organikoek zenbait ezaugarri bete behar dituzte erantzun biofotoniko aproposa izan dezaten [9]:

- Egonkortasun kimiko eta fotokimikoa. Kitzikapen intentsua eta jarraitua izanda ere, fluoroforoa ez degradatzeko eta irudi fluoreszenteak luzaro irauteko oinarrizko baldintza da.

- Absortzio/igorpen uhin-luzera aproposak, betiere ikusgaiko eremu gorrian edo infragorri hurbilean badago (uhin-luzera $>650 \mathrm{~nm}$, leiho biologikoa) hobetsiko da. Energia altuko argia ez da azalean asko barneratzen eta ehunak kaltetu ditzake. Energia baxukoa (argi gorria), aldiz, ez da hain kaltegarria, sakonago barneratzen da eta biomolekulen autofluoreszentzia ekiditen denez haren sentikortasuna nabarmen areagotzen da.

- Absortzio eta emisio banda sendoak, irudien argitasuna hobetzeko, nahiz eta erabiltzen den fluoroforoaren kantitatea txikia izan.

- Disolbagarritasuna uretan. Kromoforo organiko gehienak hidrofoboak dira, baina ingurune fisiologikoa urtsua denez, disolbagarritasuna areagotzeko talde funtzional aproposak gehitzen dira. 
- Moldakortasun kimiko bikaina. Ordezkatzaile aproposak eransteko gaitasuna edukitzea gune espezifikoak aztertzeko, analizatu nahi diren organuluekiko lotura selektiboa bermatzeko, eta aurretik aipatutako ingurune fisiologikoan disolbagarritasuna bultzatzeko.

Baldintza horiek guztiak aintzat hartuta, fluoroforo organikoek seinale fluoreszentearen monitorizazioa ahalbidetzen dute bioirudi-teknikaren bidez (1. irudia) [10], batez ere diagnosian biomolekulak etiketatzeko (markatzaileak) [11] eta detektatzeko (sentsoreak) [12], zein interesdun organuluak atzemateko (zundak) [13]. Hala ere, fluoreszentziarik ez duten molekulak ere erabilgarriak izan daitezke garrantzi handiko bestelako aplikazioetan, terapian esaterako [14]. Horrelakoetan, molekulak kitzikatu eta energiaren galera argiaren igorpenaren bidez jazo beharrean, beste egoera desberdin batera erlaxatu eta bertatik desaktibatzen dira; hots, triplete egoerara transferitu eta oxigeno singletea $\left({ }^{1} \mathrm{O}_{2}\right)$ sortzeko gai dira [15]. Oxigenoaren espezie kitzikatu hori zitotoxikoa da eta ingurunean dauden zelulak suntsitu ditzake; bada, estrategia ezin aproposagoa minbiziaren aurkako tratamendurako, eta bereziki terapia fotodinamikorako (1. irudia) [16]. Terapia horretan hiru osagai nagusi behar dira: fotosentikortzailea (FS), ${ }^{1} \mathrm{O}_{2}$ espezie aktiboa sortzeko gai dena; argi iturria, minbiziaren aurkako aktibitatea pizteko; eta oxigenoa, ingurune aerobikoa behar baita ${ }^{1} \mathrm{O}_{2}$ sorrarazteko.

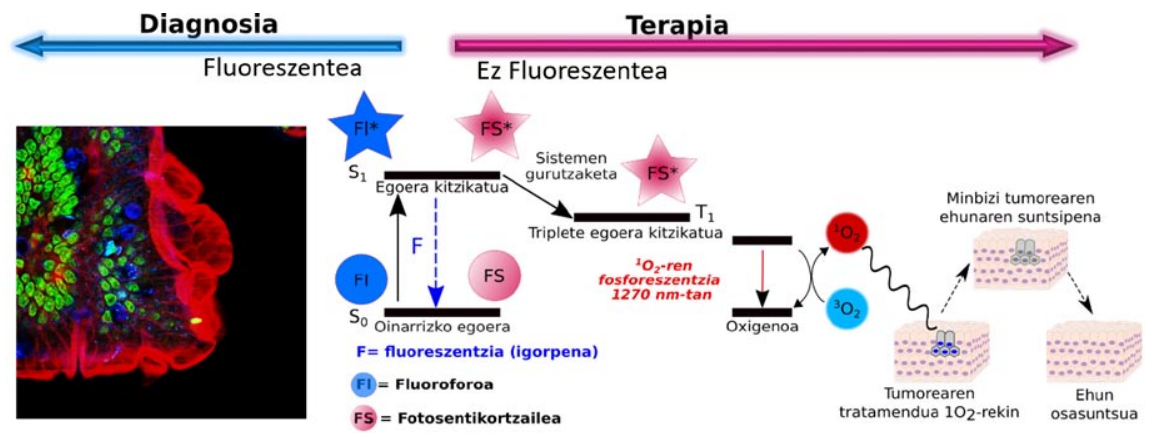

1. irudia. Fluoroforoen (Fl) eta fotosentikortzaileen (FS) kitzikapenaren ondorioz gertatzen diren desaktibazio-bide ezberdinen eskema. Fluoroforo kitzikatuak (Fl*) energia galtzean argia (fluoreszentzia) igortzen du, diagnosirako ezinbestekoa dena (sagu baten hesteetako zeharkako ebaketaren fluoreszentziako irudia adibide gisa). Fotosentikortzaileak, ordea, (FS*) triplete egoera kitzikatuaren bidez desaktibatzen dira, oxigeno singlete espezie zitotoxikoa eratuz, terapia fotodinamikoan aplikagarria. Minbizi tumorearen suntsipena adierazten duen eskema ere ageri da.

Orain arte, diagnosirako eta terapiarako koloratzaile desberdinak erabili dira, fluoroforoen eta fotosentikortzaileen ezaugarriak hain kontrajarriak izateagatik. Are gehiago, markatzaileak, sentsoreak edo zundak gara- 
tzerakoan askotan koloratzaile-familia ezberdinak erabiltzen dira aplikazio bakoitzerako. Hala ere, gaur egungo egoera guztiz aldatu da BODIPY (Boron DIPYrromethene, 2. irudia) izeneko koloratzaileak direla eta. Izan ere, ikuspuntu sintetikotik bere nukleo kromoforikoa erraz eralda daiteke eta talde funtzional ezberdin asko txerta daitezke egituraren gainean [17]. Gainera, ordezkatzaileek ezaugarri fotofisikoen modulazioa ahalbidetzen dute aurretik aipatutako intereseko propietateak lortzeko [18]. Beste era batean esanda, BODIPYan oinarritutako kromoforoa abiapuntu bezala hartuz, fluoroforoak zein fotosentikortzaileak diseinatzeko nahikoa da oinarrizko egitura kromoforikoan beharrezko transformazioak egitea, goian aipatutako aplikazio biofotonikoetarako erabili ahal izateko $[19,20]$.

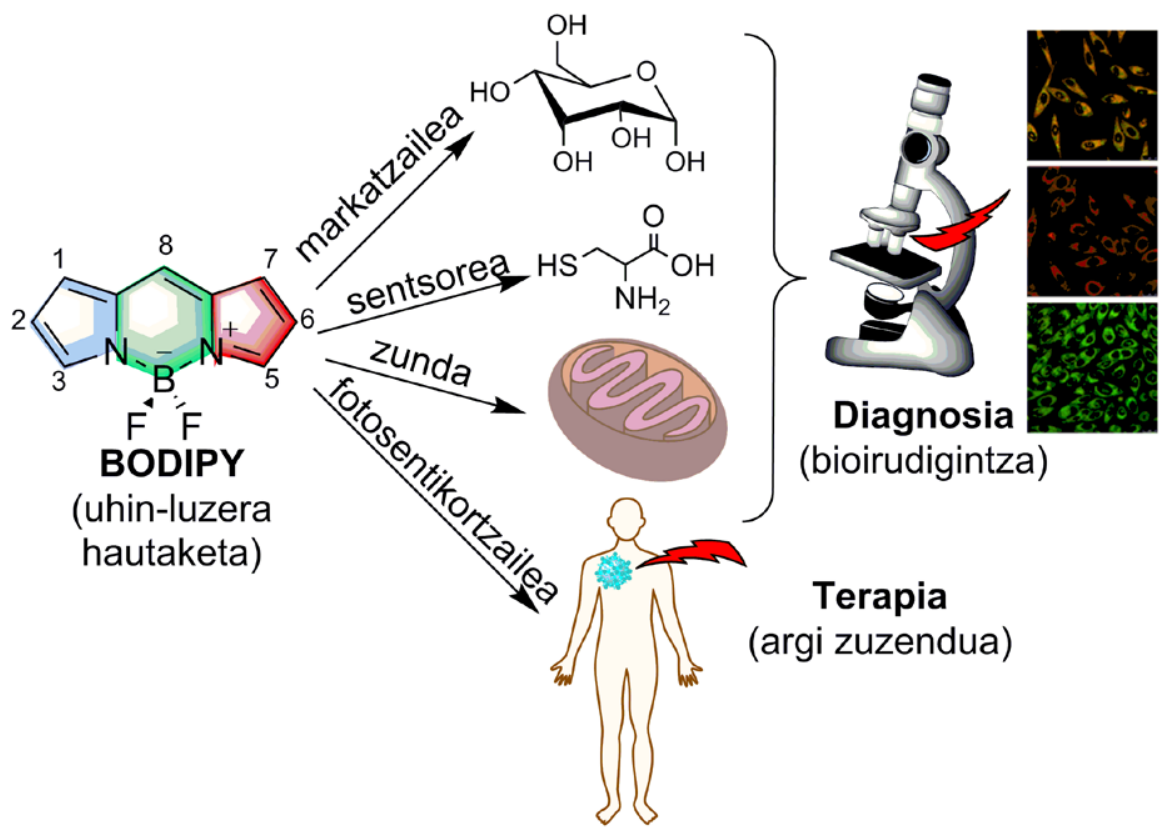

2. irudia. BODIPY kromoforoaren egitura molekularra (karbonoen posizioak zenbakituta ageri dira) eta bere aplikazio biofotonikoak: alde batetik, diagnosirako karbohidratoen etiketazioa (markatzaile fluoreszenteak), biomolekulen (zisteina aminoazidoa) detekzioa (sentsore fluoreszenteak) eta mitokondrien azterketa (zunda fluoreszenteak) mikroskopia fluoreszentearen teknikari esker; eta bestetik, terapia fotodinamikorako, alegia, minbizia sendatzeko (oxigeno singletea sortzeko gai diren fotosentikortzaileak).

Beraz, lan honen helburua da BODIPYan oinarritutako fluoroforoen eta fotosentikortzaileen adibide adierazgarriak erakustea, lehenak diagnosirako eta bigarrenak terapiarako aproposak izanik (2. irudia). Arreta bere- 
zia jarriko da diseinu molekularrean, izan ere, eskuratu nahi den aplikazio biofotoniko bakoitzak ezaugarri fotofisiko bereizgarriak aurkezten ditu, eta horretarako kontuan hartu beharreko egiturazko irizpideak ikertuko dira. Horien portaera ere analizatuko da indarguneak eta ahuleziak identifikatzeko, eta etorkizunerako hobetu beharreko ezaugarriak aipatuko dira.

Bioirudigintzarekin zerikusia duten aplikazioei dagokienez, hona hemen hiru adibide (2. irudia):

- Markatzaile fluoreszenteak. Aztertu nahi diren biomolekulak karbohidratoak izaten dira. BODIPYa sakarido bati kobalenteki lotuz gero, glikoproba deritzona lortzen da, eta horren ibilbideari gorputzean zehar jarrai dakioke denbora errealean bioirudigintzaren bidez.

- Sentsore fluoreszenteak. Bestalde, ezinbestekoa da biomolekulen presentzia detektatzea ingurune zelularrean. Horretarako, BODIPY aproposa aurkezten dugu zisteina edota tioldun aminoazidoak detektatzeko balio duena fluoreszentzia seinaleak jasandako aldaketak aztertuz.

- Zunda fluoreszenteak. Diagnosiarekin, eta bide batez bioirudigintzarekin, bukatzeko, funtsezkoa da organuluak ikusi ahal izatea. Horretarako, fluoroforo aproposak behar dira aztertu nahi den organulua selektiboki nabarmentzeko. Hala, aldehidoa daraman BODIPYa diseinatu dugu mitokondriekin elkartzeko.

Bestalde, terapia fotodinamikoan aplikatzeko, BODIPYan oinarritutako fotosentikortzailea diseinatu da eta bi entitate molekular berdin kobalenteki lotu dira. Antolakuntza geometriko horrek eta argiaren presentziak, oxigeno singletearen eraketa ahalbidetzen du, minbiziaren aurkako aktibitate terapeutikoa pizteko gakoa dena.

\section{EZTABAIDA}

\subsection{Markatzaile fluoreszenteak}

BODIPY koloratzaileak dituen balizko propietateei esker, karbohidratoak txertatu ahal zaizkio eta ezaugarri aurreratuak dituzten glikoproba fluoreszenteak sor daitezke (3. irudia) [21]. Oligosakaridoak sintetizatu nahi direnean, glikosilazio protokoloak erabiltzen dira, hots, talde babesleen txertaketaren estrategia. Hau da, behin-behineko talde babesleak (hidroxilo taldeen bentzilazioa) erabil daitezke eta amaieran eliminatu egiten dira uretan disolbagarriak diren eta babestuta ez dauden konposatuak (hidroxiloak) eratzeko. Erabilitako prozedurak bi abantaila nagusi eskaintzen ditu: lehenengoa, glikosilazio prozesuaren hasieran gehitzen da karbohidratoa eta horrek BODIPYarekin eratutako lotura eta ondoko purifikazio 
prozesua errazten du; eta bigarrena, uretan fluoreszenteak diren oligosakaridoak lortzen dira [21]. Proba fluoreszente horiek garrantzi handia dute karbohidrato-hartzaile elkarrekintzek makina bat prozesu biologikotan parte hartzen baitute [22].
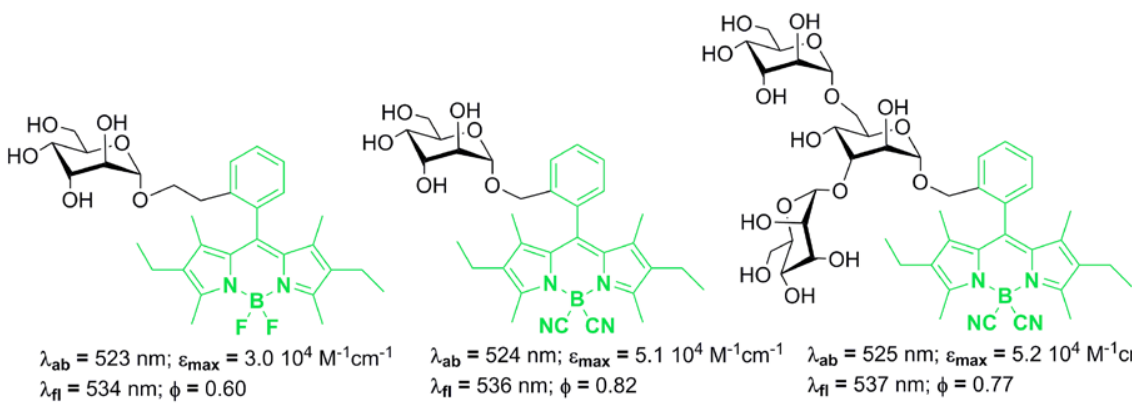

$\lambda_{\mathrm{fl}}=536 \mathrm{~nm} ; \phi=0.82$

$\lambda_{\mathrm{fl}}=537 \mathrm{~nm} ; \phi=0.77$

3. irudia. Lortutako markatzaile fluoreszenteak BODIPYa monosakaridoekin eta trisakaridoekin lotzean. Fluoroforoen ezaugarri fotofisiko nagusienak aurkezten dira uretan: absortzio $\left(\lambda_{\mathrm{ab}}\right)$ eta fluoreszentzia $\left(\lambda_{\mathrm{fl}}\right)$ uhin-luzerak, absortzio molarra $\left(\mathrm{e}_{\max }\right)$ eta fluoreszentzia etekin kuantikoa ( $\phi$ erreferentzia gisa fluoreszeina erabili da).

Gainera, BODIPYarekin lotuta dauden monosakarido eta trisakaridoek zeluletan barneratzeko prozesua errazten dute, toxikotasun maila baxuagoa agertzen baitute [22]. Izan ere, aplikazio biologiko askotarako ezinbestekoa da kromoforoak uretan aski disolbagarriak izatea, zeluletan mintz-iragazkortasunaren bitartez barneratzeko. Tamalez, BODIPYaren izaera hidrofobikoak agregazioa sortzen du eta disolbagarritasun baxuak lortzen dira, eragin nabarmena izanik seinale fluoreszentearen desagerpenean. Karbohidratoak eranstean, ordea, BODIPYaren disolbagarritasuna nabarmen areagotzen da. Izan ere, 3. irudian aurkezten diren fluoroforo guztiak uretan disolbatzen direla frogatu da $10^{-3} \mathrm{M}$-ko kontzentrazio-mailaraino [21]. Hala ere, aipatu beharra dago $10^{-4} \mathrm{M}$-ko kontzentrazioa gainditzean, agregazio prozesuak agertu eta emisio fluoreszentea desaktibatzen dela, igorpen propietateak kaltetuz [21]. Dena dela, $10^{-4}$ M-ko kontzentrazioa nahiko altua da, aplikazio biokimikoetan erabiltzeko lain, tarte horretan seinale fluoreszente argitsua mantentzen delako.

Oro har, konposatu horien ezaugarri fotofisikoak eta jatorrizko BODIPYarenak (karbohidratorik gabe) oso antzekoak dira eta diseinu molekularra izan da gakoa hori lortzeko (3. irudia). Azken finean, markatzaile fluoreszente bat garatzean bilatzen da fluoroforoak biomolekularekin lotu ondoren bere emisio-ezaugarriak mantentzea. Ildo honetatik abiatuz, karbohidratoa eransteko kokapen egokiena BODIPYaren 8-feniloa zela ikusi zen (ikusi karbonoen posizioak 2. irudian), izan ere ortogo- 
nalki kokatuta dago nukleo kromoforikoarekiko (alboko 1 eta 7 posizioetako metiloek eragindako oztopo esterikoengatik, 3. irudia) BODIPYaren ezaugarri fotofisikoetan eraginik izan barik. Beraz, 8-feniloaren orto posizioaren bidez mono eta trisakaridoak txertatu ahal dira fluoroforoa kaltetu gabe. Hori dela eta, $535 \mathrm{~nm}$ inguruan kokatutako emisio ahaltsua lortzen da uretan. Aipatzekoa da emisio ahalmena dezente areagotzen dela boroari lotuta dauden fluor atomoak ziano taldeez ordezkatzen direnean. Adibidez, mono eta trisakaridodun fluoroforoek \% 80 inguruko ahalmen fluoreszenteak (3. irudia) aurkezten dituzte uretan. Beraz, markatzaile horiek irudi fluoreszente dirdiratsu eta argiak emango dituzte mikroskopia fluoreszentean. Horrez gain, fotoegonkortasuna fluoreszentziako-irudiek luzaro iraun dezaten kontuan izan beharreko ezinbesteko parametroa da [23]. Hori frogatzeko, markatzaileak laser indartsupean irradiatu ziren denbora luzez, eta 100.000 ponpaketa pultsuren ostean laserrak eragindako intentsitate fluoreszentea aldatu barik mantentzen zela behatu zen [21].

Hortaz, BODIPYaren bitartez karbohidratoak markatzeko protokoloa arrakasta handiz bete da. Uretan disolbagarriak diren markatzaileak lortu dira bioirudigintza teknikaren bidez erraz aztertu eta luzaroan jarraitu daitezkeenak, eskaintzen duten erantzun fluoreszente eta fotoegonkortasunaren ondorioz.

\subsection{Sentsore fluoreszenteak}

Biomolekulek hainbat prozesu biokimiko eta gaixotasunetan eginkizun garrantzitsua betetzen dute. Honenbestez, ingurune fisiologikoan horien detekzioa ahalbidetzea oinarrizkotzat jotzen da [24]. Biomolekula ezberdinen artean, aminoazidoen (AA) detekzioak garrantzi handia dauka, proteinen osagaiak izateaz gain, horien kontzentrazioak (soberan/gabezia) lotura zuzena baitu hainbat gaixotasunen agerpenarekin. Adibidez, tiol taldea duen zisteina aminoazidoak (CYS) hazkunde zelularrean eta ehunen hazkundean parte hartzen du, baita toxinen aurkako defentsa zelularrean ere [25]. Are gehiago, AA horren kontzentrazioaren aldaketa gaixotasun desberdinekin lotuta dago, hala nola minbizi, alzheimer, eta beste zenbait gaixotasun kardiobaskularrekin. Hori dela eta, gaitz horiek garaiz diagnostikatzea eta euren mekanismo biokimikoa ezagutzea funtsezkoa da gaixoei tratamendu egokia eman ahal izateko. Beraz, garrantzi handikoa da horien kontrola eta kuantifikazio sentikorra eta eraginkorra egitea.

Argia igortzen duten sentsore kimikoak hautagai egokiak dira detekzio-mota hori burutzeko [12]. Horretarako, fluoroforoari hartzaile aproposa gehitu behar zaio aztertu nahi den analitoarekin elkartzeko. Horrez gain, behin hartzaileak analitoa bereganatzean, horrek aldaketa espektroskopiko neurgarria (fluoreszentzia ahalmenean edo uhin-luzeran) sortu 
Edurne Avellanal-Zaballa, Ainhoa Oliden-Sánchez, Rebeca Sola-Llano, Leire Gartzia-Rivero, Jorge Bañuelos

behar du detekzioa ahalbidetzeko. Baldintza horiek guztiak kontuan hartuz, BODIPYan oinarritutako sentsore bat diseinatu dugu tioldun CYSaren detekziorako (4. irudia) [26]. Horretarako, errezeptore bezala jokatzen duten ester asegabeak lotu dira BODIPYaren 3 eta 5 posizioetan (ikusi karbonoen posizioak 2. irudian). Funtzionalizazio horrek bi helburu nagusi betetzen ditu: alde batetik, banda espektralen desplazamendu batokromikoa eragiten du ikusgaiko eremu gorrira; eta bestetik, funtzio-talde horiek CYS biomolekularen hartzaile bezala dihardute, lotura bikoitzak eta karbonil taldeek AAaren nukleozalea den tiol taldearekin erreakzionatzeko joera baitute.

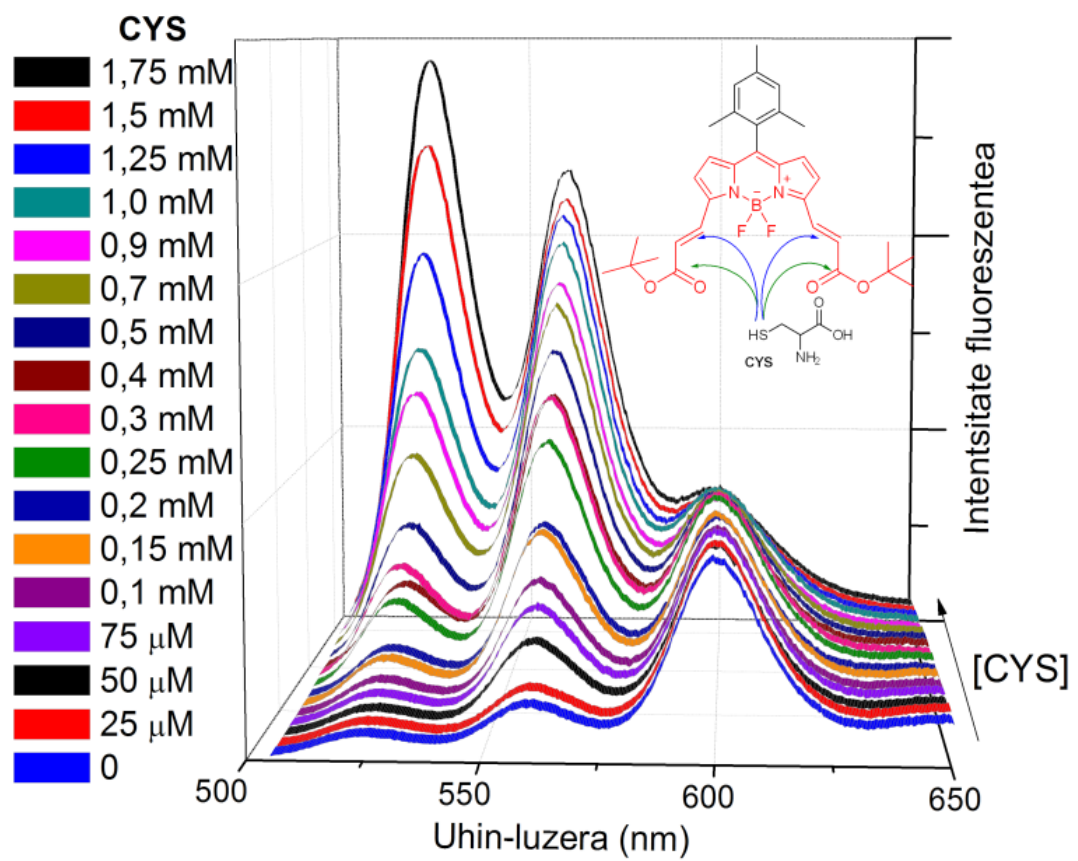

4. irudia. BODIPYan oinarritutako sentsoreak (kontzentrazioa $2 \cdot 10^{-6} \mathrm{M}$ ) jasandako aldaketa intentsitate fluoreszentean (kitzikapen uhin-luzera $500 \mathrm{~nm}$ ) CYS gehitzean (etanola/HEPES 1/1 nahastea, ingurune fisiologikoa imitatzeko). Diseinatutako BODIPYaren egitura, eta CYSaren tiol taldeek BODIPYaren ester asegabeekin eragindako elkarrekintzak eskematikoki aurkezten dira.

CYS ingurunean ez dagoenean, sentsoreak emisio banda ahaltsua erakusten du eremu gorrian (600 nm-tan zentratua, 4. irudia). Ingurunean, aldiz, CYS gehitu ahala emisio horren intentsitatea murriztu egiten da eta emisio berri bat agertzen da $560 \mathrm{~nm}$ inguruan (4. irudia). Are gehiago, CYSaren kontzentrazio altuagoa erabiltzean (milimolar inguru- 
koa) beste emisio banda berri bat agertzen da (525 nm-tan, 4. irudia). Beraz, BODIPYan oinarritutako sentsore hori oso sentikorra da adierazle ratiometriko gisa, hiru detekzio kanal eskuragarri baitaude: $600 \mathrm{~nm}-\mathrm{koa}$, (igorpen gorria) intentsitate fluoreszentearen jaitsieraren bidez detektagarria; eta batez ere, $560 \mathrm{~nm}$ (igorpen laranja) eta $525 \mathrm{~nm}$-ko (igorpen horia) bandak, intentsitate fluoreszentearen igoera nabariaren bidez erabilgarriak direnak, eta honenbestez, hiruren artean eraginkorrenak direnak. Horrez gain, detekzioa emisio kolore-aldaketari esker ere burutu daiteke modu erraz batean, disoluzioaren igorpen-kolorea laranjatik horira aldatzen baita CYSaren kontzentrazio baxuetan, eta horitik berdera kontzentrazio altuetan (5. irudia). Hortaz, sentsore ratiometrikoa izateaz gain, aldi berean sentsore kolorimetrikoa diseinatu dugula esan daiteke, non CYSaren presentzia berehala sumatu daitekeen mikroskopia fluoreszentearen bidez. Gainera, detekzio hori modu kuantitatiboan egin daitekeela frogatu da, izan ere, CIE deituriko kolore digramatik abiatuta (5.A irudia) dagokion kalibrazio-kurba hiru-dimentsionala eraiki da (5.B irudia), zeinetan, BODIPYaren emisioaren CIE kolore-koordenatuak ( $\mathrm{x}, \mathrm{y}$ ) ezagutuz gero, dagokion aminoazidoaren (kasu honetan zisteina) kontzentrazio zehatza determinatu daitekeen (5.B irudiko ekuazioak erabiliz).

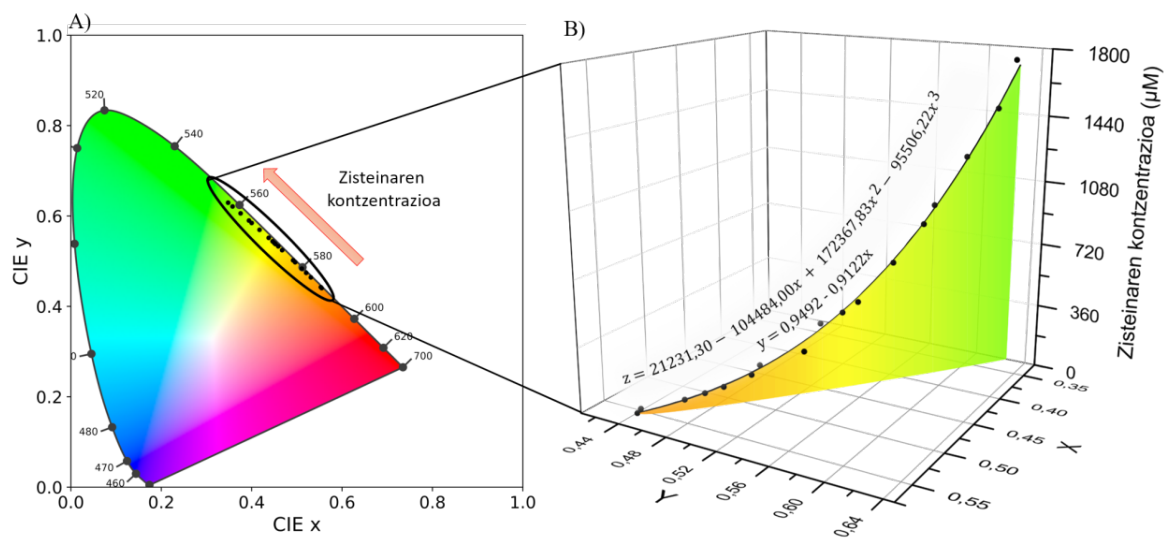

5. irudia. A) CIE 1931 kolore eremuaren diagraman BODIPYaren emisioaren kokapenaren eboluzioa CYS gehitu ahala (geziaren norantzan); B) Zisteinaren kontzentrazio bakoitzerako ( $\mathrm{z}$ ardatza) CIE diagramaren $\mathrm{x}$ eta y koordinatuak irudikatu dira eta hiru dimentsioko grafikoa lortu da (kolore-kodea bat dator CIE diagramako zonalde horretan behatutakoarekin). Funtzio polinomiko bat erabili da enpirikoki lortutako datuen joera esponentziala doitzeko, dagokion kalibraziokurba tridimentsionala lortuz (ekuazioak atxikita).

Detekzioa CYSaren eta kromoforoaren artean sortzen den erreakzio mekanismoari esker egiten da, CYSeko nukleozalea den tiol taldearen 
eta kromoforoaren ester asegabeen (biniloa eta karboniloa erreakzio-gune gisa) arteko erreakzio kimikoari esker hain zuzen ere (4. irudia). Elkarrekintza horren ondorioz $\pi$-sistemaren hedapena txikiagotu eta uhin-luzera baxuagoetan seinale fluoreszente berri bat agertzen da. Hots, CYS eta karboniloaren arteko elkarrekintza selektiboak (gezi berdea, 4. irudian) BODIPY nukleoaren $\pi$-sistemaren hedapena murriztuko lukete BODIPY 3,5-biniloekin soilik geratu arte (560 $\mathrm{nm}$-ko fluoreszentziaren arduraduna). Binilo talde horiekin beste elkarrekintza (gezi urdina, 4. irudian) osagarri bat ematekotan, orduan eta gehiago murriztuko litzateke $\pi$-sistema harik eta BODIPY nukleoa hutsik gelditu arte $(525 \mathrm{~nm}$-ko fluoreszentzia banden erantzulea izanez).

Aipatu beharra dago, aurkeztu dugun BODIPYan oinarritutako sentsore ratiometriko eta kolorimetrikoak tiol taldeak dituen beste AA batzuekiko ere sentikortasuna aurkezten duela; besteak beste homozisteinarekiko (HCYS), bere molekula-egitura zisteinaren oso antzeko izanik, eta glutationarekiko (GSH), azken horren sentikortasuna, ordea, aurrekoarena baino askoz ere baxuagoa izanik [26]. Ziur aski, GSHaren tamaina handia izango da elkarrekintzak ez sortzearen erantzulea, oztopo esterikoen eraginez.

\subsection{Zunda fluoreszenteak}

Biofotonikaren ezaguerak diagnosirako aplikatzen direnean, zunda fluoreszenteak asko erabiltzen dira organuluen detekzioa eta azterketa egiteko [27, 28]. Horretarako, teknika aurreratu eta sentikorrena fluoreszentziako mikroskopiak eskainitako irudi fluoreszenteen analisia da. Aztergai diren organuluen artean mitokondriek arreta berezia jaso dute, izan ere, funtsezkoak dira zeluletan energia ekoizteko eta horien bizi-iraunkortasunaren edo heriotzaren determinazioan [29]. Gainera, mitokondriak jasandako gorabeherek (tamainan, egituran edo morfologian) hainbat patologiaren agerpenarekin, hala nola, desordena metaboliko edo infekzio birikoekin, zerikusi handia dute. Hori dela eta, mitokondrien kalitatezko bioirudia izatea giltzarria da hainbat patologia (minbizia edo koronabirusa) garaiz diagnostikatzeko.

Gaur egun, hamaika zunda fluoreszente daude eskuragarri mitokondriak tindatzeko eta horien jarraipen espezifikoa egiteko (mitotrackers) [30]. Gehienek talde kationikoak (amonioa edo fosfonioa) izaten dituzte, mitokondriek duten potentzial gradiente negatiboarekin elkartu ahal izateko. Hala ere, elkarrekintza mota horiek mitokondriaren funtzionamendua alda dezakete, eta horrez gain, zunda horietako asko ez dira egonkorrak edo bateragarriak izaten organuluekiko. Oztopo horiek zunden erabilera izugarri mugatzen dute zelula bizietan. Hori dela eta, mitokondria kaltetu gabe hura selektiboki tindatzeko, zunda berri eta hobeen garapenean dihardute ikertzaileek. 
Behar hori asetzeko asmoz, BODIPY koloratzailea berriz ere hautagai aproposa da. Mitokondrien detekzioa ahalbidetzeko formilo taldea txertatu da kromoforoaren 3 posizioan (6. irudia) [31]. Egitura-aldaketa sinple hori gai da BODIPYaren eta organuluan dauden proteinen amino taldeen arteko erreakzioa bultzatzeko, eta bide batez hori tindatzeko zunda fluoreszente neutro bat erabiliz, potentzial elektrikoan inongo eraginik izan barik.

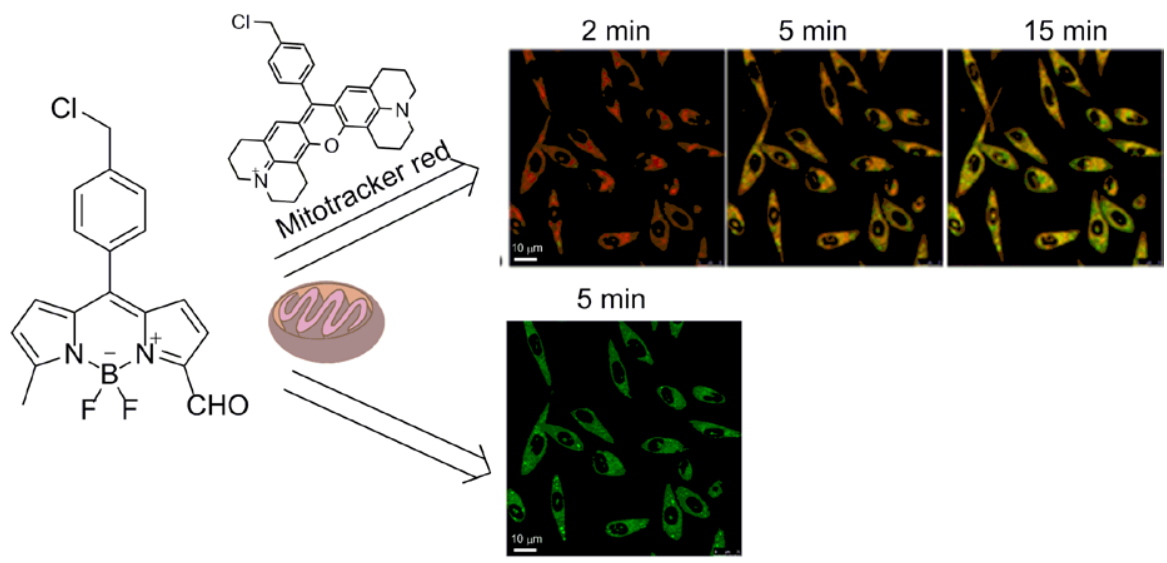

6. irudia. Mitokondriak ikusteko BODIPYan oinarritutako zunda fluoreszentearen egitura eta bere metatze abiadura organuluan barrena (nanomolar kontzentrazioan). PC-3 prostata minbizi zelulak inkubatu ziren «mitotracker red» (goian) zundarekin eta gabe (behean). Fluoreszentzia irudietako eskala-barra $=10 \mu \mathrm{m}$.

Mitokondriak tindatzeko ahalmena egiaztatzeko in vitro saioak egin ziren PC-3 prostata minbizi zelula erabiliz eta irudi fluoreszenteak lortu ziren mikroskopio konfokalaren bidez (6. irudia) [31]. Formilodun BODIPYa zeluletan barneratzen da (2 minututan) eta mitokondrietan oso azkar (5 minutu igarota) metatzen dela ikus daiteke. Beraz, mitokondriak eraginkortasun handiz tindatu direla esan daiteke, izan ere, lortutako igorpen berdedun irudi fluoreszentea oso distiratsua eta egonkorra baita (irudiak luzaro irauten du nahiz eta irradiazio jarraitua eta indartsua erabili). Formilodun BODIPYak mitokondriak eraginkortasunez tindatzen dituela egiaztatzeko, aurretiaz Mitotracker red deituriko koloratzailearekin inkubatutako zelulak erabili ziren. Mitotracker red konposatua mitokondriak tindatzeko gehien erabiltzen den zunda komertziala da. 6. irudian beha daitekeen bezala, nahiz eta igorpen gorridun zunda jada mitokondrietan egon, gure aztergaia den BODIPYa erraz barneratzen da zelulan, organulu berdinetan metatuz eraginkortasun handiz. Are gehiago, denbora pasa ahala bere igorpen berdea nagusitzen dela ikus daiteke (behatu kolore aldaketa 6. irudian, denbora desberdinetako fluoreszentzia-irudietan). Beraz, esan daiteke lan 
Edurne Avellanal-Zaballa, Ainhoa Oliden-Sánchez, Rebeca Sola-Llano, Leire Gartzia-Rivero, Jorge Bañuelos

honetan aurkeztutako koloratzailea eraginkorragoa dela bioirudigintzan erabiltzeko ohiko Mitotrackerrarekin alderatuz, mitokondriak ikuskatzeko teknika aski errazagoa baita. Gainera, sortzen den metaketa hori ez da toxikoa zeluletarako, eta bereziki mitokondriekiko selektiboa da, ingurunean lisosomak egonda ere mitokondriak soilik tindatzen direlako.

Ondorioz, BODIPYan oinarritutako balizko zunda fluoreszentea garatu $\mathrm{da}$, sinplea eta eraginkorra, mitokondriak selektiboki eta modu errazean ikusteko. Lortutako materialak irudi fluoreszente iraunkorrak eta argiak lortzeko eskakizunak betetzen ditu: biobateragarria da, azkar barneratu eta metatzen da, eta bereziki kimikoki zein fotokimikoki egonkorra da.

\subsection{Oxigeno singlete fotosentikortzaileak}

Printzipioz, pentsa daiteke fluoreszenteak ez diren koloratzaile organikoak biofotonikarako aproposak ez direla. Baieztapen hori, hala ere, diagnosiari buruz hitz egiten dugunean soilik betetzen da. Izatez, koloratzaile batzuk fluoreszenteak ez izan arren, kitzikapenaren ondorioz horien triplete egoera popula dezakete sistemen arteko gurutzapenaren bidez (Intersystem Crossing, ISC) eta interesgarriak dira terapia aplikazioetarako (1. irudia) [32]. Sarreran aipatu bezala, oxigeno singletea eratzeko ISC prozesuak sustatu behar dira eta argia erabiltzen da hasarazle. Izan ere, tripletearen energia aproposa da ingurugiroko oxigenoa kitzikatzeko. Hori gertatzeko, triplete egoera kitzikatuan dagoen koloratzaileak $(\mathrm{FS} *)$ eta oinarrizko egoeran dagoen oxigenoak $\left({ }^{3} \mathrm{O}_{2}\right.$, bere oinarrizko egoeran) talka egin behar dute. Eratutako oxigeno-espezie kitzikatu hori oso erreaktiboa eta zitotoxikoa da. Beraz, fotosentikortzailea (FS), hau da, oxigeno singletea $\left({ }^{1} \mathrm{O}_{2}\right)$ sortzeko gai den koloratzailea, minbiziaren tumoretik hurbil kokatzen bada baldintza aerobikoetan, argiaren menpe jartzean oxigeno singletea in situ sortu eta alboko zelulak suntsituko ditu, minbizi zelulak barne (1. irudia) [33]. Beraz, terapia fotodinamikoa alternatiba aproposa da minbizia sendatzeko, gainerako teknikek (kimioterapia edo radioterapia) osasunean eragiten dituzten albo-ondorioak saihesten direlako. Kontutan izan behar da, oxigeno singletea soilik FSaren inguruan eta bakarrik argiaren presentzian eratzen dela; hau da, ilunpean ez dago eragin terapeutikorik eta ondorioz fotosentikortzailea ezin da aktibatu. Beraz, konposatua ez da toxikoa izango ehunetarako baldintza horietan.

Normalean, BODIPY koloratzaileak oso fluoreszenteak izaten dira eta fotosentikortzaileak izateko beharrezkoa dena ez dute erakusten, alegia, triplete egoera populatzeko gaitasuna. Hala ere, egituraren moldakortasun sintetikoari esker posiblea da beharrezkoa den ISC prozesua faboratzea [34], baina, horren eraginez, seinale fluoreszentea nabarmen jaisten da. Normalean, hori lortzeko erabiltzen den estrategia nagusia egitura kromoforoari atomo astunak lotzean datza (halogenoak). Horiek ISC prozesua 
ahalbidetzen dute, baina triplete egoeraren bizitza-denbora balio baxuak lortzen dira eta gainera, atomo astunak erabiliz gero, toxikotasuna areagotzen da irradiaziorik ez dagoenean, euren biobateragarritasuna txikiagotuz. Ondorioz, halogenorik gabeko FSak diseinatzeko estrategia berriak bilatzen ari dira [35]. Oxigeno singletea eratzeko estrategia arrakastatsuenetariko bat BODIPYan oinarritutako dimeroak erabiltzea da, non bi molekula homologo elkarren artean lotzen diren (7. irudia) [36]. Oztopo esterikoa dela eta (loturaren alboan dauden metiloengatik), kromoforoak elkarrekiko ortogonalki kokatzen dira eta antolakuntza geometriko horri esker, kitzikapenaren ondorioz karga-transferentziazko prozesu intramolekularrak pizten dira (Intramolecular Charge Transfer, ICT) [37]. Argiak sortutako prozesu bitxi hau gakoa da dimero horretan [26], zubi bezala jokatzen baitu ondoren triplete egoera populatzeko, eta hemendik ${ }^{1} \mathrm{O}_{2}$ eraginkortasun handiz sortzeko (7. irudia).

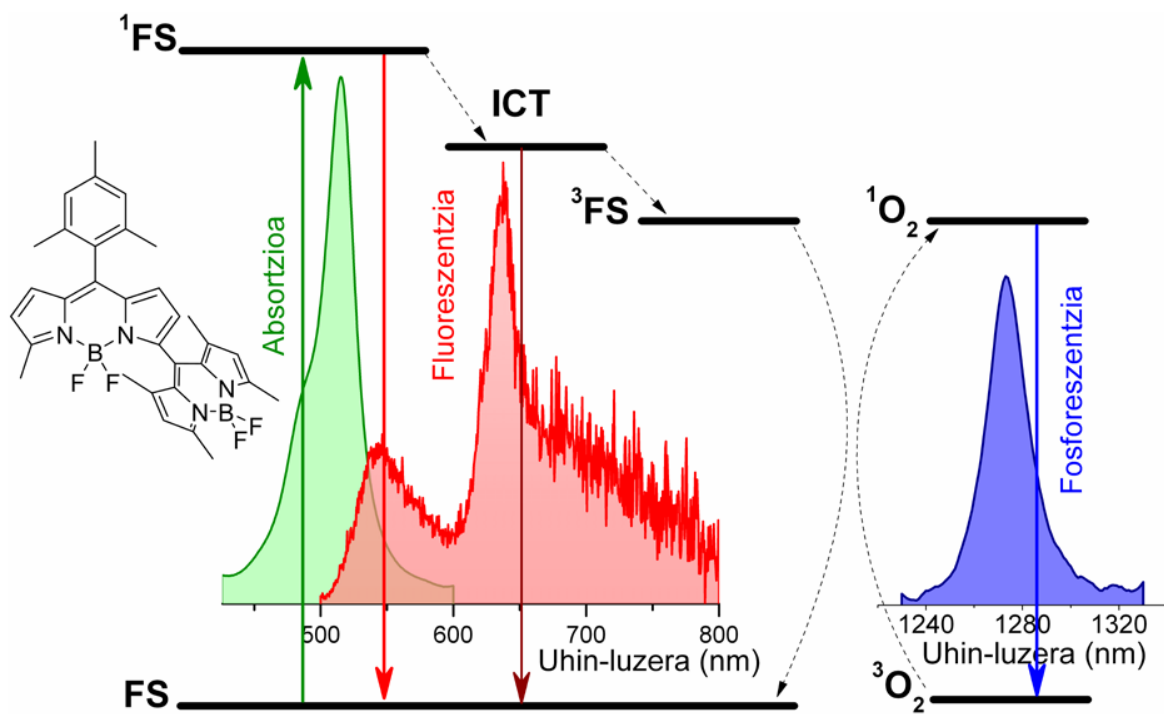

7. irudia. BODIPYan oinarritutako fotosentikortzailea. Oxigeno singletea sortzeko parte hartzen duten egoera kitzikatuen eskema (gezi etenek prozesu ez-erradiatzaileak adierazten dituzte, eta jarraituek erradiatzaileak), baita FSaren absortzio eta fluoreszentzia espektroak, eta oxigeno singletearen fosforeszentzia (toluenotan, $490 \mathrm{~nm}$-tako uhin-luzeran kitzikatuta) ere aurkezten dira.

Espero zen bezala kromoforoaren seinale fluoreszentea oso ahula da (espektroak oso zaratatsuak, ikusi 7. irudia) eta horrekin batera, fluoreszentzia-ahalmena ere eskasa da $(<\% 5$ etekin kuantikoa [26]). Joera horrek ICT prozesu baten presentzia iradoki dezake, baina badaude ezaugarri fluoreszente bereizgarri batzuk prozesu horren bideragarritasuna froga- 
tzeko. Fluoreszentzia espektroan bi igorpen ageri dira, $540 \mathrm{~nm}$-tan esperotakoa eta beste bat $640 \mathrm{~nm}$ inguruan kokatuta dagoena, azken hori ICTaren emisio ahulari dagokio (7. irudia). Argiak sortutako egoera berri horrek oso izaera polarra dauka, kargak banatzea eragiten baitu. Horregatik, ingurunearen polaritatearekiko oso sentikorra da eta egoera hori egonkortzean seinale fluoreszentea ia guztiz galtzen da (etekin fluoreszentea $<\% 1$ ingurune polarrean [26]). Dimero simetriko horretan dagoen ICTa oso bitxia da ezin baita ziurtatu zein den alde elektroi-emailea eta zein hartzailea (ohiko ICTa aurkezten duten molekuletan erraz nabarmentzen dira bi zati horiek, eta euren artean ematen da karga-transferentzia). Beraz, bere sorrera-mekanismoa bestelakoa izan behar dela ondorioztatu daiteke: simetria-galera baten ondorioz ematen den karga-transferentzia (Symmetry Breaking Charge Transfer, SBCT). Hau da, prozesuan parte hartzen duten zatien arteko antolamendu geometriko ortogonalak agintzen du karga-banaketa [37].

Behin ICT egoera horretan, triplete egoera popula daiteke. Azken trantsizio hori ahalbidetzen duen mekanismo zehatza oraindik ez da guztiz ezaguna eta hainbat teoria proposatzen dira [35]. Argi dago sistemen arteko gurutzaketa ahalbidetzeko ICT prozesuak pisu handia daukala, eta hori egon ezean ez litzatekeela triplete egoerara iritsiko (ikusi 7. irudian ICT egoeratik ${ }^{3} \mathrm{FS}$ egoerara gerta daitekeen trantsizio ez-erradiatzailea). ICT egoera horretan karga bi kromoforoen artean banatuta dago. Ingurunearen baldintzen arabera (polaritatea batez ere) karga banaketa hori egonkortu daiteke edo, bestalde, kargak konbina daitezke. Bi prozesu horiek lehian daude eta horien arteko orekaren arabera triplete egoeraren sorrera handiagoa edo txikiagoa izango da. Nahiz eta bibliografian horri buruzko eztabaida handia egon, guztietan aipatzen dute ICTan ematen den karga-konbinazioa gakoa dela triplete egoerara heltzeko. Behin egoera horretan, oxigeno singletearen sorrera eraginkorra bermatzen da (\% 30-\% 54 bitartekoa ingurunearen polaritatearen arabera [26]) inguruko oxigenotik abiatuz.

Hortaz, halogenorik gabeko oxigeno fotosentikortzailea lortu da, minbizi gaixotasunetarako sendagai gisa erabil daitekeena. Beste hitz batzuetan, argiaren bidez zuzendutako balizko terapiarako balio duen sendagaia lortu da, ilunpean toxikotasun arbuiagarria duena.

\section{ONDORIOAK ETA ETORKIZUNEKO IKUSPEGIAK}

Lan honetan, diagnosirako eta terapiarako biofotonikaren bideragarritasuna eta egokitasuna frogatu da moldagarria den molekula organiko fotoaktibo bakarra oinarri gisa erabiliz. BODIPYan oinarritutako fluoroforoen adibide adierazgarriak erakutsi ditugu diagnosirako, hala nola, karbohidratoak etiketatzeko, tioldun aminoazidoak detektatzeko edota mito- 
kondriak tindatzeko. Bestalde, terapian aplikatu ahal den fotosentikortzaile bat ere garatu da eredu berdinetik abiatuz oxigeno singletea sortzeko.

Hala ere, bioteknologian oraindik erronka ugari gainditu behar dira sistema fotoaktibo horiek hobetzeko, batez ere, sarreran aipatutako baldintza guztiak betetzen dituen funtzio anitzeko BODIPY kromoforoak garatu nahi direnean:

- Sakaridoen markatzaileak oso fluoreszenteak dira uretan baina euren portaera biofotonikoa hobetzeko asmoz komenigarria izango litzateke emisioa alde gorrira edo infragorri hurbilera bultzatzea. Karbohidratoa BODIPYaren 8-feniloan txertatuta dagoenez, gainontzeko kromoforoaren posizioak libre daude talde aromatikoak gehitzeko eta $\pi$-sistema hedatzeko, batez ere 3 eta 5 posizioak erabil daitezke banden desplazamendu batokromikoak eskuratzeko.

- Zisteinarako sentsore kolorimetriko eta ratiometrikoaren portaera hobetzeko helburuarekin disolbagarritasuna handitu beharko litzateke uretan. Horretarako funtzio-talde aproposak gehitu ahal dira 8-feniloan edo boro zubian, horien ordezkapenak ez baitu eraginik fluorofoaren ezaugarri fotofisikoetan.

- Mitokondriarako zunda fluoreszentearen kasuan onuragarria izango litzateke ingurune urtsuan disolbagarritasuna bermatzea eta horrez gain, igorpena espektro ikusgaiaren alde gorrira desplazatzea. Horretarako, aurreko puntuan aipatutako estrategiak berriro ere aplika daitezke, kontutan izanik formilo taldeak bere baitan jarraitu behar duela.

- Fotosentikortzailearen oxigeno singletea sortzeko ahalmena oso ona da. Hala ere, etekin baxuagoa ere nahikoa izango litzateke minbizi zelula hiltzeko. Beraz, oxigeno singletea sortzeko gai den eta aldi berean fluoreszentzia mantentzen duen BODIPYa oso interesgarria izango litzateke. Modu honetan diagnosia eta terapia aldi berean burutu ahal izango lirateke koloratzaile fotoaktibo bakar bat erabiliz. Lehian dauden bi prozesu horien baturari teragnosia deritzo (terapia + diagnosia) eta bertan aplikatu ahal izateko dimeroaren geometriarekin jokatu beharra dago (BODIPY unitate ezberdinak, lotura posizio ezberdinak,...). Behin fluoreszentzia eta oxigeno singletearen arteko oreka egokia lortuta, aurretik esandako ingurune fisiologikoan disolbagarritasuna hobetzea, igorpena leiho biologikora desplazatzea, eta baita minbizi tumorearekin selektiboki elkartzeko talde aproposak eranstea, izango lirateke hurrengo erronkak.

BODIPYaren kimika aberatsak itxaropen handia ematen digu etorkizunerako, egitura eraldaketen bidez diseinu aproposak modu errazean erdiets baitaitezke. 
Edurne Avellanal-Zaballa, Ainhoa Oliden-Sánchez, Rebeca Sola-Llano, Leire Gartzia-Rivero, Jorge Bañuelos

\section{ESKER ONAK}

Artikulu hau Eusko Jaurlaritzak emandako diru-laguntzari esker (IT912-16 proiektua) gauzatu da. Era berean, E. Avellanal-ek MINECO eskertzen du, doktore-ondoko kontratuagatik, eta A. Oliden-ek UPV/EHU, doktore-aurreko bekagatik.

\section{BIBLIOGRAFIA}

[1] SINKELDAM, R.W., GRECO, N.J., TOR, Y. 2010. «Fluorescent analogs of biomolecular building blocks: design, properties and applications». Chem. Rev., 2010, 110, 2579-2619.

[2] LOVELL, J.F., Liu, T.W.B., Chen, J., Zheng, G. 2010. «Activatable photosensitizers for imaging and therapy». Chem. Rev., 110, 2839-2857.

[3] BETZIG, E. 2015. «Single molecule, cells, and super-resolution optics». Angew. Chem. Int. Ed., 54, 8034-8053.

[4] HELL, S. W. 2015. «Nanoscopy with focused ligth». Angew. Chem. Int. Ed., 54, 8054-8066.

[5] MOERNER, W.E. 2015. «Single-molecule spectroscopy, imaging, and photocontrol: foundations for super-resolution microscopy». Angew. Chem. Int. Ed., 54, 8067-8093.

[6] DE MOLINER, F., KIELLAND, N., LAVILLA, R., VENDRELL, M. 2017. «Modern synthetic avenues for the preparation of functional fluorophores». Angew. Chem. Int. Ed., 56, 3758-3769.

[7] KULYK, O., ROCARD, L., MAGGINI, L., BONIFAZI, D. 2020. «Synthetic strategies tailoring colours in multichromophoric organic nanostructures». Chem. Soc. Rev., 49, 8400-8424.

[8] DSOUZA, R.N., PISCHEL, U., NAU, W.M. 2011. «Fluorescent dyes and their supramolecular host/guest complexes with macrocycles in aqueous solutions». Chem. Rev., 111, 7941-7980.

[9] COLAS, K., DOLOCZKI, S., URRUTIA, M.P., DYRAGER, C. 2021. «Prevalent biomaging scaffolds: synthesis, photophysical properties and applications». Eur. J. Org. Chem., 2021, 2133-2144.

[10] ZHU, S., TIAN, R., ANTARIS, A.L., CHEN, X., DAI, H. 2019. «Near-infrared-II molecular dyes for cancer imaging and surgery». Adv. Mater., 31, 1900321.

[11] THOMAS, B., YAN, K.-C., HU, X.-L., DONNIER-MARECHAL, M., CHEN, G.-R., HE, X.-P., VIDAL, S. 2020. «Fluorescent glycoconjugates and their applications». Chem. Soc. Rev., 49, 593-641.

[12] WU, D., SEDGWICK, A.C., GUNNLAUGSSON, T., AKKAYA, E.U., YOON, J., JAMES, T.D. 2017. «Fluorescent chemosensors; the past, present and future». Chem. Soc. Rev., 46, 7105-7123. 
[13] KOWADA, T., MAEDA, H., KIKUCHI, K. 2015. «BODIPY-based probes for the fluorescence imaging in living cells». Chem. Soc. Rev., 44, 49534972.

[14] LI, X., KOLEMEN, S., YOON, J., AKKAYA, E.U. 2017. «Activatable photosensitizers; agents for selective photodynamic therapy». Adv. Funct. Mater., 27, 1604053.

[15] OGILBY, P.R. 2010. «Singlet oxygen: there is indeed something new under the sun». Chem. Soc. Rev., 39, 3181-3209.

[16] MAJUMDAR, P., NOMULA, R., ZHAO, J. 2014. «Fluorescent glycoconjugates and their applications». J. Mater. Chem. C, 2, 5982-5997.

[17] BOENS, N., VERBELEN, B., ORTIZ, M.J., JIAO, L., DEHAEN, W. 2019. «Synthesis of BODIPY dyes through postfunctionalization of the boron dipyrromethene core». Coord. Chem. Rev., 399, 213024.

[18] BAÑUELOS, J. 2016. «BODIPY dye, the most fluorophore ever?». Chem. Rec., 16, 335-348.

[19] KAUR, P., SINGH, K. 2019. «Recent advances in the application of BODIPY in bioimaging and chemosensing». J. Mater. Chem. C, 7, 1136111405 .

[20] AGAZZI, M.L., BELLATORE, M.B., DURANTINI, A.M., DURANTINI, E.N., TOME, A.C. 2019. «BODIPYs in antitumoral and antimicrobial photodynamic therapy: an integrating review». J. Photochem. Photobiol. C, 40, 21-48.

[21] URIEL, C., PERMINGEAT, C., VENTURA, J., AVELLANAL-ZABALLA, E., BAÑUELOS, J., GARCIA-MORENO, I., GOMEZ, A.M., LOPEZ, J.C. 2020. «BODIPYs as chemically stable fluorescent tags for synthetic glycosylation strategies towards fluorescently labeled saccharides». Chem. Eur. J., 26, 5388-5399.

[22] BARATTUCCI, A., CAMPAGNA, S., PAPAliA, T., GAlletA, M., SANTORO, A., PUNTORIERO, F., BONACCORSI, P. 2020. «BODIPY on board of sugars: a short enlightened journey up to the cells». ChemPhotoChem, 4, 647-658.

[23] DEMCHENKO, A.P. 2020. «Photobleaching of organic fluorophores: quantitative characterization, mechanisms, protections». Methods Appl. Fluoresc., 8, 022001.

[24] KOLEMEN, S., AKKAYA, E.U. 2018. «Reaction-based BODIPY probes for selective bio-imaging». Coord. Chem. Rev., 354, 121-134.

[25] ZHANG, J., WANG, N., JI, X., TAO, Y., WANG, J., ZHAO, W. 2020. «BODIPY-based fluorescent probes for biothiols». Chem. Eur. J., 26, 41724192.

[26] RAMOS-TORRES, A., AVELlANAL-ZABALlA, E., PRIETO-CASTANEDA, A., GARCIA-GARRIDO, F., BAÑUELOS, J., AGARRABEITIA, A.R., ORTIZ, M.J. 2019. «FormylBODIPYs by PCC-promoted selective oxidation of $\alpha$-methylBODIPYs. Synthetic versatility and applications». Org. Lett., 21, 4563-4566. 
[27] CHAN, J., DODANI, S.C., CHANG, C.J. 2012. «Reaction-based small-molecule fluorescent probes for chemoselective bioimaging». Nature Chem., 4, 973-984.

[28] LI, H., VAUGHAN, J.C. 2018. «Switchable fluorohores for single-molecule localization microscopy». Chem. Rev., 118, 9412-9454.

[29] HERST, P.M., ROWE, M.R., CARSON, G.M., BERRIDGE, M.V. 2017. «Functional mitochondria in health and disease». Front. Endocrinol., 8, 296.

[30] JOHNSON, I., SPENCE, M. (eds.) 2010. The molecular probes ${ }^{\circledR}$ handbook: a guide to fluorescent probes and labelling technology. 11th edition, Life Technologies, USA.

[31] RAMOS-TORRES, A, AVELLANAL-ZABALLA, E., GARCIA-GARRIDO, F., FERNANDEZ-MARTINEZ, A.B., PRIETO-CASTAÑEDA, A., AGARRABEITIA, A.R., BAÑUELOS, J., GARCIA-MORENO, I., LUCIO-CAZAÑA, F.J., ORTIZ, M.J. 2021. «Mitochondria selective trackers for long-term imaging based on ready accessed neutral BODIPYs». Chem. Commun., 57, 5318-5321.

[32] ZHAO, J.; WU, W., SUN, J.; GUO, S. 2013. «Tripler photosensitizers: from molecular design to applications». Chem. Soc. Rev., 42, 5323-5351.

[33] ABRAHAMSE, H., HAMBLIN, M.R. 2016. «New photosensitizers for photodynamic therapy». Biochem. J., 473, 347-364.

[34] KAMKAEW, A., LIM. S.H., LEE, H.B., KIEW, L.V., CHUNG, L.Y., BURGESS, K. 2013. «BODIPY dyes in photodynamic therapy». Chem. Soc. Rev., 42, 77-88.

[35] ZHAO, J.; CHEN, K., HOU, Y., CHE, Y., LIU, L., JIA, D. 2018. «Recent progress in heavy atom-free organic compounds showing unexpected intersystem crossing (ISC) ability». Org. Biomol. Chem., 16, 3692-3701.

[36] CHEN, K., DONG, Y., ZHAO, X., IMRAN, M., TANG, G., ZHAO, J., LIU, Q. 2019. «BODIPY derivatives as triplet photosensitizers and the related intersystem crossing mechanisms». Front. Chem., 7, 821.

[37] KELLOG, M., AKIL, A., SYLVINSON, D., RAVINSON, M., ESTERGREEN, L., BRADFORTH, S.E., THOMPSON, M.E. 2019. «Symmetry breaking charge transfer as a means to study electron transfer with no driving force». Faraday Discuss., 216, 379-394. 